\title{
Children on Drugs
}

\author{
Richard Wilmot* \\ Clinical Director/ Path to Recovery, USA
}

Submission: May 25, 2017; Published: June 02, 2017

*Corresponding author: Richard Wilmot, Clinical Director/ Path to Recovery, College of Alameda, STAFF PSYCHOLOGIST /SCHUMAN-LILES CLINIC OAKLAND, Ca Expertise: dual diagnosis/drug/ alcohol counseling/ self-help mental health/education \& research 1995-2000, Drug Education Specialist: California Youth Authority, Oakland Parole Office, Tel: 510 459-8301; Email: dr.docwilmot@gmail.com

\section{Opinion}

Whenever a politician wants to rouse the public to champion a policy all he or she has to do is invoke the name of children: "it's all about the children"; "it's for our children," "it's to protect the children." There is a lot of hypocrisy and disingenuousness attached to such an invocation, as poverty and the lack of health care - two of the most manifest endangerments to children - seem to be perennially ignored. Likewise, if one wishes to provoke intense public scrutiny all one has to do is mention children and drugs in the same sentence. If they are so juxtaposed, then the link between them had better emphasize their contrast and conflict. There is nothing good to say about the use of drugs by children ... except by children themselves and only when adults are not present. Perhaps we should put down the Ritalin and simply listen to them.

Of course children know better than to say anything to an adult that could in anyway be construed as favorable towards drugs. Although among themselves, they will reveal their true feelings. It is too dangerous to talk frankly with an adult about drugs. There are sanctions. There is pain and punishment ... hurt feelings. Why bother? And it is just such a conspiracy of silence and self-censorship that places us in the position we are today: awash with drugs and drug problems with only clichés to say out loud about them. We are now engaged in yet another war - a civil war (for the children) against drugs, except it appears that the "enemy" is becoming a little more devious, a little more stealthy, and is hiding in common, ordinary household products and personal grooming aids such as finger nail polish and nail polish remover, spray paint, marking pens, spray on solvents, and whip cream dispensers. These are the products used in inhalant abuse, and although one does not necessarily need to be a child to use them, it is understood that a troublesome percentage of both adolescents and preadolescents do so.

Who is this enemy in these products that threaten our children? NIDA director Nora Volkow [1], MD, identified the enemy in her article "Youth and Inhalant Abuse" - the enemy is the "quick high" [1].
Tell us more about this "quick high" threat to our children. But alas, throughout the remainder of the article, "quick high" is never mentioned again. Perhaps that is because of the profane reputation of the word "high" itself. It is really a "quick (\& dirty) high".

Be that as it may, now that the "enemy" has been identified, let us bring on the war! What should be our weapons to keep children off inhalants? Aerosol sprays, propellants, and solvents are not good things to inhale; on that we can all agree. However to ban such products because of their possible abuse would be absurd. It is incredulous to consider the makers of glue, shoe polish, paint thinner or gasoline as drug pushers. So the weapon of prohibition seems out of the question. What about propaganda? Perhaps if children knew just how bad it was for both their mental and physical health, they would cease and desist. Yet, as Volkow points out, studies indicate that users report that they "abuse inhalants in spite of known negative consequences." And after a lengthy description of just how negative those negative effects can be, Dr. Volkow [1] concludes with this prevention tip: "A solution to this problem ... aims to educate children and others about the dangers and risks involved." In other words: more propaganda about the negative effects of "huffing," "snorting" and "bagging" that children, as Volkow reports, do not listen to anyway [1].

How can we get the children to listen? Perhaps we should listen to them, and if not through words, at least from a different angle - through their actions (i.e., behaviorally). Dr. Volkow made the comment: "It is difficult to understand why anyone would stuff a solvent-soaked rag in their mouth, and begin huffing the concentrated vapors." Perhaps the reason has to do with that "quick high" mentioned at the beginning of her article.

When Sigmund Freud first proposed "infantile sexuality" his conjecture was considered absurd. Nowadays, childhood erotica is viewed as a normal part of psychological development and genital manipulation is observable behavior in infants. Our knowledge about psychoactive drugs and particularly 
drug use by children seems to be at a similar parochial stage of understanding as was sex at the turn of the last century. However, just as Freud postulated sex as a universal drive, many experts in the field of drug studies are beginning to recognize that "getting high" is also a universal drive. Ronald Siegel, Andrew Weil, Stuart Walton and others have observed that "getting high" or altering one's consciousness is an evolutionary inevitability having to do with our human biology. To paraphrase Siegel: "getting high" is as natural as falling in love [2].

Weil also calls our attention to the natural orientation of children to alter their consciousness: The desire to alter consciousness is an innate psychological drive arising out of the neurological structure of the human brain. Strong evidence for this idea comes from observations of very young children, who regularly use techniques of consciousness alteration on themselves and each other when they think no adults are watching them. These methods include whirling until vertigo and collapse ensue, hyperventilating and fainting. Such practices appear to be universal, irrespective of culture, and present at ages when social conditioning is unlikely to be an important influence (two and three years old). Psychiatrists have paid little attention to these activities of all children. Freud noted them and called them 'sexual equivalents' which they may be, although that formulation is not very useful [3].

In his book Out of It, Walton [4] describes the death of a 15-year-old boy at Eton College resulting from a game of recreational asphyxiation, which had been all the rage in Britain's famous public school. In this asphyxiation game, intelligent adolescents from functional homes choked each other into unconsciousness by tying cloth cords around each other's necks and tightening them until one's playmate collapsed. When asked to explain the reason for such behavior one of the participants said: "The attraction was that it was something different. It makes you feel abnormal."

Spinning until dizzy or asphyxiating until close to passing out and experiencing the disorientation and hilarity that such an altered state can produce are the same motivational triggers for doing drugs, whether it be inhaling nitrous oxide from an empty whip cream dispenser or smoking marijuana. The need to alter one's consciousness is a perfectly natural drive. When children attempt to "get high" they are doing something natural. They are playing. Adults who use spinning to promote spiritual mysticism
(Sufi Dervishes) or enhance their sexual foreplay through erotic asphyxiation are using a child's game to do the same thing: alter their consciousness.

If we can view a child's motivation for getting "high" as part of a universal desire to alter consciousness, we will have a better understanding of how to deal with abuse. What the child is doing is natural, but the tools he or she may be employing may be dangerously inappropriate. Approached in this way, we will have a better rapport with the child, and on that basis, be better informed as to what our children are doing. No longer do we have to threaten the child by saying: "What in the hell are you doing that for or why in the hell are you taking that stuff." Such a prohibitive reaction simply 'shouts' down further communication. We can bypass the inquisition because we will already know. We can then say: "I know how you feel when you do this or take that ... this is natural ... I'm just concerned you might hurt yourself. Here is why."

\section{Conclusion}

It should be noted that one of main propellants used in aerosols is nitrous oxide, considered the most abused of all other gases. William James [5], the father of modern American recovery psychology, used nitrous oxide himself in his experiments on human consciousness. He titrated his dose and created for himself a uniquely religious experience that he wrote about in his now classic work The Varieties of the Religious Experience. Do children have such experiences themselves when they ingest such drugs as nitrous oxide? Perhaps it is time that we ask them. Maybe the answer to childhood drug abuse is to begin a dialogue with children on drugs that recognize the fact that what they are doing is natural (not necessarily pathological or immoral) but also can be dangerous, and that our concern is over the danger and not about the alteration of consciousness itself.

\section{References}

1. Volkow, Nora (2006) Youth and Inhalant Abuse. Counselor, The Magazine for Addiction Professionals 7: 2.

2. Siegel, Ronald K (1989) Intoxication: Life in Pursuit of Artificial Paradise. E.P. Dutton, New York, USA.

3. Weil, Andrew (1972) The Natural Mind. Houghton Mifflin, Boston, USA.

4. Walton, Stuart (2002) Out of It. Three Rivers Press, New York, USA.

5. James, William (1929) Varieties of the Religious Experience. Longman Green, London, UK. 


\section{Your next submission with Juniper Publishers} will reach you the below assets

- Quality Editorial service

- Swift Peer Review

- Reprints availability

- E-prints Service

- Manuscript Podcast for convenient understanding

- Global attainment for your research

- Manuscript accessibility in different formats ( Pdf, E-pub, Full Text, Audio)

- Unceasing customer service

Track the below URL for one-step submission https://juniperpublishers.com/online-submission.php 